GLOBAL INDUSTRY, LOCAL INNOVATION:

THE HISTORY OF CANE SUGAR PRODUCTION IN AUSTRALIA, 1820-1995 



\section{GLOBAL INDUSTRY, LOCAL INNOVATION: THE HISTORY OF CANE SUGAR PRODUCTION IN AUSTRALIA,}

1820-1995

\section{PETER D. GRIGGS}

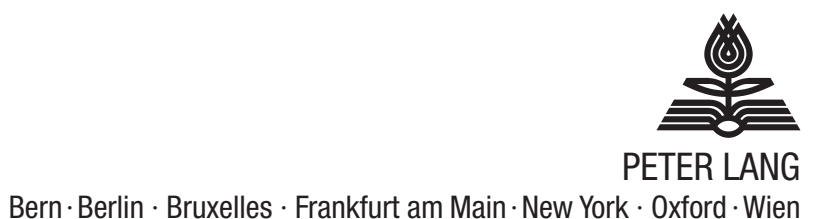




\section{Bibliographic information published by Die Deutsche Nationalbibliothek}

Die Deutsche Nationalbibliothek lists this publication in the Deutsche Nationalbibliografie; detailed bibliographic data is available on the Internet at «http://dnb.d-nb.de».

British Library Cataloguing-in-Publication Data: A catalogue record for this book is available from The British Library, Great Britain

Library of Congress Cataloging-in-Publication Data

Griggs, P. D. (Peter D.)

Global industry, local innovation : the history of cane sugar production in Australia, 1820-1995 / Peter D. Griggs.

p. $\mathrm{cm}$.

Includes bibliographical references.

ISBN 978-3-0343-0431-3

1. Sugar trade-Australia-History-19th century. 2. Sugar trade-Australia-History-20th century.

3. Sugar growing-Australia-History-19th century. 4. Sugar growing-Australia-History-

20th century. 5. Sugar-Manufacture and refining-Australia-History-19th century. 6. SugarManufacture and refining-Australia-History-20th century. 7. Sugarcane-Australia-History19th century. 8. Sugarcane-Australia-History-20th century. 9. Australia-Economic conditions-19th century. 10. Australia-Economic conditions-20th century. I. Title. HD9118.A8G75 2010

338.1'73610994-dc22

2010045491

Cover illustration: Cover Illustration of The Australian cane sugar industry,

issued by the sugar industry organisations, 1938.

Cover design: Thomas Jaberg, Peter Lang AG

ISBN 978-3-0343-0431-3

(c) Peter Lang AG, International Academic Publishers, Bern 2011

Hochfeldstrasse 32, CH-3012 Bern, Switzerland

info@peterlang.com, www.peterlang.com,www.peterlang.net

All rights reserved.

All parts of this publication are protected by copyright.

Any utilisation outside the strict limits of the copyright law, without the permission of the publisher, is forbidden and liable to prosecution.

This applies in particular to reproductions, translations, microfilming, and storage and processing in electronic retrieval systems.

Printed in Germany 
For Tracey and in memory of Emma J. Fells 



\section{Contents}

Acknowledgements

ix

A note on statistics and currency xiii

A note on geographical boundaries and place names xiv

Abbreviations used in footnotes and table and figure captions $\quad \mathrm{xv}$

Illustrations xviii

Glossary of sugar terms and definitions xxix

1. An Introduction 1

2. Sugar Cane and The Production of Sugar 9

PART ONE 1788 TO 1863: BEGINNINGS 19

3. Intermittent Attempts at Sugar Production 21

4. The Rise of the Colonial Sugar Refining Company 31

PART TWO 1864 TO 1914: BECOMING ESTABLISHED 41

5. The Spread of Sugar Cane Cultivation 43

6. The Production Unit: Planters, Central Millers and Small Farmers 73

7. Science and the Canegrowers 123

8. The Milling Sector 175

9. Competing for the Sugar Basin: Refiners, Merchants and the Australian Sugar Market

PART THREE 1915 TO 1995: EXPANSION, EXPORTORIENTATED AND REGULATED 269

10. A Regulated Expansion 271

11. Growing the Crop: Cultivation Methods, Implements
and Plant Nutrition

12. Managing Water 397

13. Breeding and Improving Cane Varieties 467

14. Combatting Pests 521

15. Defeating Cane Diseases 565

16. Harvesting and Transport of Cane 613 
17. Regulating and Modernising the Milling Sector

18. The Refining, Marketing and Pricing of Sugar

19. Conclusion

Select Bibliography

Index 


\section{Acknowledgements}

The research and writing for this volume has been conducted over the past fifteen years, being sandwiched between my normal teaching commitments. It has involved a journey to Scotland in 1995 and numerous journeys to libraries and archives in Canberra, Brisbane, Sydney and Melbourne and to the sugar-producing districts throughout eastern Australia. In a work of such duration and complexity, I have contracted far more debts than can be acknowledged in detail. Many people have contributed freely with material, information and advice and by discussion and criticism. Their encouragement and shared interest have assisted greatly, and I here record my warm thanks to all of them.

James Cook University has supported the work through financial assistance and the granting of four periods of study leave. The maps and diagrams were drawn by Adella Edwards in the Cartography Office, School of Earth and Environmental Sciences, James Cook University. Her skill in turning my hand-drawn draft maps into such appealing finished maps never ceases to amaze me. The librarians at the Cairns Campus have been so supportive, especially Vaurian Lewin and Beth Barnes who managed the inter-campus loans, and Lyn Clark and Janine Meakin who arranged for the numerous inter-library loans. Jean Main, Ann Bolton, Sandi Robb and Tara Day were very helpful research assistants during the project.

This book would not have been possible without access to the archival records of CSR Ltd. I am extremely indebted to CSR Ltd. for allowing me to read through the firm's pre-1980 historical records and for permission to reproduce illustrative material which appears as Figure 6.5 and Plates 7.3, 8.3, 8.6, $11.1,12.1,12.2,12.3,15.2$ and 16.3. Several other sugar milling companies also granted access to their records and provided hospitality during research visits. I gratefully acknowledge the assistance provided by the Proserpine Cooperative Sugar Milling Association Ltd., Mossman Central Mill Company Ltd. and the Mackay Sugar Cooperative Association Ltd. In addition, the New South Wales Cane Growers' Association allowed access to their historical records, enabling a New South Wales perspective to be added to this book.

I owe thanks to the following institutions and their staffs for the use of material in their custody and for help over the years: in Victoria, the State Library of Victoria, the ANZ Group Archive, the National Australia Bank Group Archives, Melbourne University Archives and the Public Record 
Office Victoria; in New South Wales, the State Records Authority of New South Wales, the State Library of New South Wales and Southern Cross University Library; in Queensland, the Fryer Memorial Library, The University of Queensland, Queensland State Archives, Queensland Department of Primary Industries Library and the Queensland Department of Natural Resources and Water Library; in Scotland, Glasgow University Archives; and in Canberra, the National Library, National Archives of Australia and the Noel Butlin Archives Centre, Australian National University. In particular, I am very indebted to the following current and former staff at the Noel Butlin Archives Centre: Penny Pemberton, Maureen Purtell, Emma Jolley, Tatiana Antsoupova, Mary Paton and Sarah Lethbridge. These archivists over the years retrieved countless boxes of CSR records from 'the tunnel' and provided warm welcomes and hot cups of tea to a visitor from Queensland who often ended up in Canberra during its coldest months. Deborah Martin, Librarian and Records Archivist, at BSES Limited, Brisbane, assisted greatly by providing biographical details on past scientists who worked for the Queensland Bureau of Sugar Experiment Stations.

Chapter Six contains part of my 1997 paper 'The origins and development of the small cane farming system in Queensland, 1870-1915' that originally appeared in the Journal of Historical Geography and my 2000 paper 'Sugar plantations in Queensland, 1864-1912' that originally appeared in Agricultural History. Sections of Chapter 7 appeared originally in my 2003 paper 'Australian scientists, sugar cane growers and the search for new gummosis-resistant and sucrose-rich varieties of sugar cane, 1890-1920' that was published in the Historical Records of Australian Science and my 2004 paper 'Improving agricultural practices: science and the Australian canegrowers, 1864-1915' that was published in Agricultural History. Chapter 9 includes part of my 2001 paper 'The decline of competition: the emergence of a duopoly in the Australian sugar refinery sector, 1841-1915' that was originally published in the Australian Geographer. The detail on soil erosion in Chapter 12 comes from my 2005 paper 'Soil erosion, scientists and the development of conservation tillage techniques in the Queensland sugar industry, 1935-1995', which originally appeared in Environment and History. Information about the attempts to control cane grubs in Chapter 14 originally appeared in my 2005 paper, 'Entomology in the service of the state: Queensland scientists and the campaign against cane beetles, 1895-1950' and the methods developed to control cane diseases discussed in Chapter 15 was published in my 2007 paper, 'Defeating cane diseases: plant pathologists and the development of disease control strategies in the Australian 
sugar industry, 1920-1950'. Both were published in the Historical Records of Australian Science. I am grateful to the editors of the following journals and copyright owners for permission to reproduce this material: Agricultural History Society (Agricultural History); The White Horse Press (Environment and History); Elsevier (Journal of Historical Geography); Geographical Society of New South Wales (Australian Geographer); and CSIRO Publishing (Historical Records of Australian Science).

I gratefully acknowledge the permission of the following organisations to reproduce their illustrative material as photographs in this book: Part 1 photograph; Mitchell Library, State Library of New South Wales; Plates 8.2 and 8.4; Mackay Regional Council Libraries; Plates 5.1, 6.2, 7.1, 8.1, 8.7, 16.1 and 18.1; John Oxley Library, State Library of Queensland; Part 2 photograph and Plate 6.1; Fryer Library, The University of Queensland; Plates 7.2, 9.1 and 9.2; State Library of Victoria; Part 3 photograph and Plates 12.4 and 16.5; National Library of Australia; Plate 11.4; National Archives of Australia; Plates 11.7 and 18.4; CANEGROWERS, Brisbane; Plates 7.5, 11.5, 11.6, 12.5, 13.2, 13.3, 14.1, 14.3, 14.4, 15.1, 15.5 and 17.5; BSES Limited; Plate 16.2; Gold Coast City Council Local Studies Library; Plates 16.6, 17.1 and 17.2; Sunshine Coast Libraries; Plates 16.7, 16.9, 16.10, 16.11, 17.4, 17.6, 17.7, 18.2 and 18.5; Rural Press Queensland Pty. Ltd.; Plate 16.8; Burdekin Shire Library; Plate 18.3; Queensland Department of Transport and Main Roads; and Plate 17.3; Australian Cane Farmers Association Limited.

Several colleagues have read different parts of this book. I am particularly indebted to Professor John Weaver, McMaster University, for his encouragement over the years, his very helpful comments on the entire manuscript and his suggestion about the book's title. I am also very appreciative of the comments provided by the following academics and scientists over the years: Professor Emeritus Jock Galloway, University of Toronto; Professor Emeritus Phillip Courtenay, James Cook University; Dr Mac Hogarth, current Editor of the Proceedings of the International Society of Sugar Cane Technologists and former Group Manager for Cane Breeding and Improvement, Queensland Bureau of Sugar Experiment Stations; Mr Brian Egan, the former Coordinator of the Cane Pest and Disease Control Boards in Queensland and pathologist with the Queensland Bureau of Sugar Experiment Stations; and Dr Ralph Shlomowitz, Flinders University.

I am extremely grateful to Daniela Christen at Peter Lang AG, who initially showed such enthusiasm for the book. More recently, I have been ably guided by Katrin Forrer who has seen the project through to completion. Her advice and guidance has been much appreciated. 
Families ultimately become involved in the research for a book. Mine have been no exception. My special thanks are extended to my parents, Jack and Veronica Griggs, and my father-in-law, John Rowan. They answered numerous questions about the historical development of the Australian sugar industry between 1930 and 1985, drawing upon their experiences as owners of a cane farm and as an employee of Pioneer Sugar Mills Pty. Ltd., respectively.

My greatest thanks, however, are to my partner Tracey, and our children Thomas, Llewellyn and Emma, who accepted the absence of their father and partner during his many trips away and who survived the ordeal of the last eighteen months of virtual non-stop writing with such generosity and patience.

P.D.G.

Cairns 


\section{A note on statistics and currency}

Metric measures have been used in this book, except where there is significance in the Imperial units. No attempt, however, was made to convert predecimal Australian currency units into modern day equivalents. All currency units are expressed in Australian pounds ( $\mathfrak{E}$ ), shillings (s), and pence (d), unless stated otherwise. 


\section{A note on geographical boundaries and place names}

Throughout this book, reference is made to specific regions in Queensland where sugar cane is cultivated. Definitions of these regions are as follows: North Queensland is Mackay northwards; Far North Queensland is Tully northwards to Mossman; Central Queensland encompasses the Proserpine and Mackay districts; Southern Queensland is Bundaberg southwards; and the Wide Bay-Burnett region included the Bundaberg, Isis (or Childers) and Maryborough districts.

Modern spellings of place names and modern place names have been used throughout the book. 


\section{Abbreviations in footnotes and table and figure captions}

$\begin{array}{ll}\text { ABARE } & \text { Australian Bureau of Agricultural and Resource Economics } \\ \text { AC } & \text { Australian Canegrower } \\ \text { ADB } & \text { Australian Dictionary of Biography } \\ \text { AEMCo. } & \text { Australian Estates and Mortgage Company Limited } \\ \text { AER } & \text { Australian Estates and Mortgage Company Limited Records } \\ \text { AONSW } & \text { Archives Office of New South Wales, Sydney (now State } \\ & \text { Records Authority of New South Wales) } \\ \text { ANZA } & \text { ANZ Group Archive, Melbourne } \\ \text { APCQ } & \text { Air Pollution Council of Queensland } \\ \text { AR } & \text { Annual Report } \\ \text { ASMC } & \text { Australian Sugar Milling Council } \\ \text { ASSCT } & \text { Australian Society of Sugar Cane Technologists } \\ \text { ASJ } & \text { Australian Sugar Journal } \\ \text { ATCJ } & \text { Australian Town and Country Journal } \\ B C & \text { Brisbane Courier } \\ \text { BCSM } & \text { Bureau of Central Sugar Mills, Queensland. } \\ \text { BOA } & \text { Bank of Australasia } \\ \text { BOAR } & \text { Bank of Australasia Records } \\ \text { BRC } & \text { Business Records Centre, Glasgow University Archives } \\ \text { BSES } & \text { Queensland Bureau of Sugar Experiment Stations } \\ \text { CBCS } & \text { Commercial Banking Company of Sydney } \\ \text { CBCSR } & \text { Commercial Banking Company of Sydney Records, National } \\ & \text { Australia Bank Group Archives, Melbourne } \\ C G Q B & \text { Cane Growers' Quarterly Bulletin } \\ C R E & \text { Clarence and Richmond Examiner } \\ C P P & \text { Commonwealth Parliamentary Papers } \\ \text { CSR } & \text { Colonial Sugar Refining Company } \\ \text { CSRR } & \text { Colonial Sugar Refining Company Records } \\ \text { Doc. } & \text { Document } \\ \text { Ev. } & \text { Evidence } \\ \text { FISCC } & \text { Fruit Industry Sugar Concession Committee } \\ H R A & \text { Historical Records of Australia } \\ H R N S W & \text { Historical Records of New South Wales } \\ \text { HRV } & \text { Historical Records of Victoria } \\ \text { IAC } & \text { Industries Assistance Commission } \\ & \end{array}$




$\begin{array}{ll}\text { Insp. } & \text { Inspector } \\ \text { ISSCT } & \text { International Society of Sugar Cane Technologists } \\ \text { IWSC } & \text { Irrigation and Water Supply Commission, Queensland. } \\ \text { J. } & \text { Journal } \\ \text { JCUA } & \text { James Cook University Archives, Townsville } \\ \text { JOL } & \text { John Oxley Library, Brisbane } \\ \text { LW } & \text { Logan Witness } \\ \text { Mang. } & \text { Manager } \\ \text { MC } & \text { Maryborough Chronicle } \\ \text { Melb. } & \text { Melbourne } \\ \text { ML } & \text { Mitchell Library, Sydney } \\ \text { MM } & \text { Mackay Mercury } \\ \text { MUA } & \text { Melbourne University Archives } \\ \text { NBAC } & \text { Noel Butlin Archives Centre, Australian National Univer- } \\ & \text { sity, Canberra } \\ \text { NBAM } & \text { National Australia Bank Group Archives, Melbourne } \\ \text { NS } & \text { Northern Star } \\ \text { NSW } & \text { New South Wales } \\ \text { NSWCGA } & \text { New South Wales Cane Growers' Association } \\ \text { NSWVP } & \text { New South Wales Votes and Proceedings } \\ \text { PDT } & \text { Port Denison Times } \\ \text { PMR } & \text { Pioneer Mill Records } \\ \text { Proc. } & \text { Proceedings } \\ \text { Q } & \text { Queenslander } \\ \text { QAG } & \text { Queensland Auditor-General } \\ \text { QAJ } & \text { Queensland Agricultural Journal } \\ \text { QCGC } & \text { Queensland Cane Growers Council } \\ \text { QGG } & \text { Queensland Government Gazette } \\ \text { Qld. } & \text { Queensland } \\ \text { QNB } & \text { Queensland National Bank } \\ \text { QNBR } & \text { Queensland National Bank Records } \\ \text { QPP } & \text { Queensland Parliamentary Papers } \\ \text { QPD } & \text { Queensland Parliamentary Debates } \\ \text { QSA } & \text { Queensland State Archives } \\ \text { QSB } & \text { Queensland Sugar Board } \\ \text { QSC } & \text { Queensland Sugar Corporation } \\ \text { QSSCT } & \text { Queensland Society of Sugar Cane Technologists } \\ \text { QVP } & \text { Queensland Votes and Proceedings } \\ \text { RRE } & \text { Richmond River Express } \\ & \end{array}$


SAPP South Australian Parliamentary Papers

Sec. Secretary

SJTC Sugar Journal and Tropical Cultivator

SRI Sugar Research Institute, Queensland

UB Union Bank of Australia

UBR Union Bank of Australia Records

VPRO Victorian Public Record Office, Melbourne

WQCQ Water Quality Council of Queensland

Note: All archival material of the Colonial Sugar Refining Company was located at the Noel Butlin Archives Centre, Australian National University, Canberra, unless stated otherwise. 


\section{Illustrations}

\section{Plates}

2.1 A cluster of cane stalks, known as a stool

5.1 A gang of European canecutters in the sugar cane fields near Ingham, 1904

6.1 Eatonvale plantation, Copenhagen Bend, Mary River, c. 1890

6.2 A gang of Pacific Islanders hoeing young sugar cane in the Herbert River district, possibly on Macknade plantation, c. 1902

6.3 Australian workers objecting to Indians working on New South Wales sugar plantations

7.1 Hand planting of cane by Pacific Islanders in the Mackay district, c. 1870

7.2 Part of a wood engraving showing the irrigation facilities of Pioneer plantation, near Ayr, 1889

7.3 Seedling cane trials at the Hambledon Cane Nursery, c. 1902

7.4 A twelve month old crop of Badila cane in the Innisfail district, 1915

7.5 Part of Edmund Jarvis' drawing of the metamorphosis of the greyback cane beetle (Dermolepida albohirtum Waterhouse) and the damage caused to the roots of stalks of sugar cane, 1916

8.1 Major A.J. Boyd's sugar mill at Ormeau plantation, near Beenleigh

8.2 Pacific Islanders feeding sticks of harvested cane into the crushing rollers at Alexandra Mill, near Mackay, c. 1868

8.3 The interior of CSR's Goondi Mill, near Innisfail, showing the mechanical cane carrier and crushing rollers, 1905

8.4 Horse-drawn carts loaded with harvested cane beside the Palms Mill, near Mackay, 1895

8.5 A sugar boiler testing the syrup in a vacuum pan at an unidentified Australian sugar mill, c. 1886

8.6 Mechanical cane grab unloading punts filled with harvested cane at the Broadwater Mill wharf, 1907

8.7 A rake of loaded cane trucks being hauled over a narrow gauge tramline to Isis Mill, 1896 
8.8 An overhead, circle boom type cane derrick at Hodel Siding, Ayr Tramway, 1911

8.9 Davids mechanical unloaders in operation at Bingera Mill, 1909212

8.10 Hand-loading bagged sugar into a lighter at Mackay for transfer to a southern ocean-going steamer anchored at Flat Top Island, 1911

9.1 The Victoria Sugar Co.'s Yarraville Refinery, 1876

9.2 The interior of the Victoria Sugar Co.'s Yarraville Refinery, 1881241

11.1 Weeding cane mechanically by the use of Hodge Rotary Weeders, Green Hill, near Cairns, 1949

11.2 A side view of a Howard Rotary Cultivator, showing the blades and drive casing, attached to an early model tractor

11.3 A cutter planter being pulled by a Caterpillar tractor, 1935

11.4 A Hodge cane planter in operation, 1953

11.5 A Don Gough trash planter in operation, c. 1976

11.6 Tractor-mounted powder mister applying herbicides for vine control, 1971

11.7 A billet planter in action, c. 1995

12.1 Excavating a new drain that formed part of the extension to the Robb Swamp Drainage Scheme, c. 1918

12.2 A Toft hydraulic loader fitted with a clam-shell type grab being used to create a farm-based drain in the Innisfail district, c. 1960

12.3 A levelling frame being used to remove small depressions in a paddock so as to improve field drainage

12.4 Hand shift sprinklers being used to irrigate young cane on a farm in the Mackay district, 1963

12.5 Plastic irrigation tubing on a Queensland cane farm, c. $1970 \quad 446$

13.1 Voile-covered crossing lanterns in use at the Meringa BSES station, c. 1953

13.2 A first ratoon crop of Badila (left) and Trojan (right), showing the superior vigour of the latter CSR-bred cane variety

13.3 Hand weighing stalk samples during a field trial in Southern Queensland, c. 1959

14.1 A comparison of an experimental plot injected with paradichlorbenzene (on left) and an untreated plot (on right), six months after treatment

14.2 A farmer demonstrating the use of the Dank's injector to fumigate soil 
14.3 The Blundell knapsack fumigant injector

14.4 Ratoon crop failure attributed to soldier fly in the Innisfail district, c. 1968

15.1 The main symptoms of Fiji disease: stunted stools (bottom left) displaying leaf galls (shown in the inset)

15.2 Leafhoppers (Perkinsiella saccharicida, Kirk) on cane leaves

15.3 The impact of ratoon stunting disease on the Q. 28 cane variety (left of photograph). Healthy Q. 28 appears on the right

15.4 Hand dipping of setts against pineapple disease

15.5 Baskets of setts being loaded into a hot-water treatment tank at Isis Mill, near Childers, c. 1957

16.1 Canecutters in the Tully district laying portable rail track, c. 1930

16.2 The Falkiner mechanical cane harvester during a demonstration run, Pimpama Island district, 1925

16.3 Jib-type grab loaders mounted on turntables being used to fill rail trucks, Fairymead plantation, 1948

16.4 The earliest type of Toft loader showing the loading of harvested cane onto a motor lorry, 1940

16.5 A front-end cane loader being used in the Mackay district, 1959

16.6 A Crichton whole stalk mechanical cane harvester operating in the Moreton Mill supply area, August 1962

16.7 The Massey-Ferguson mechanical chopper cane harvester in operation, 1958

16.8 Loaded rail trucks waiting for unloading at Invicta Mill, c. 1925

16.9 A 9-10 tonne canetainer loaded onto an infield trailer hauled by a tractor, Mossman district, c. 1970

16.10 An elevating side-tipper field bin loading a canetainer, 1975

16.11 Harvested cane being transferred from a multi-lift prime mover to a transloader, which delivered the cane into cane bins destined for Bingera Mill, Bundaberg district, 1976

17.1 Plate and frame filter presses at Moreton Mill, c. 1945

17.2 Installing new effets at Moreton Mill, 1952

17.3 A Donnelly chute on No. 2 set of crushing rollers, Pioneer Mill, 1958

17.4 The cooling pond at Qunaba Mill, c. 1965

17.5 The diffuser at Inkerman Mill, 1977

17.6 A rotary tippler in operation at Fairymead Mill, c. 1974 
17.7 Australia's first continuous vacuum pan for cane sugar production at Mossman Mill, 1976

18.1 Mechanical conveyor loading of bagged sugar at the Port of Cairns, 1939

18.2 The sugar bin at Pioneer Mill, c. 1965 (right foreground) 797

18.3 An aerial view of the Lucinda bulk sugar terminal, $1969 \quad 800$

18.4 One of the 1985 television advertisements promoting sugar in Australia

18.5 A sketch of the Manildra Harwood Sugars Refinery and Harwood Mill complex showing the sugar shed, foreground, the refinery, centre, and mill, background, c. 1990 
Figures

2.1 The main sugar-producing districts in Australia (past and current) 13

2.2 Frost free areas of Australia 14

3.1 Localities around Port Macquarie where sugar cane was cultivated in the $1820 \mathrm{~s}$

5.1 Area (ha) under sugar cane in Queensland and New South Wales, 1864-1914 46

5.2 Distribution of sugar cane cultivation in Australia, 1874 and $1884 \quad 47$

5.3 Distribution of sugar cane cultivation in Australia, 1894, 1904 and 1914

6.1 The approximate locations of North Queensland sugar plantations

6.2 The approximate locations of the New South Wales sugar plantations and four of CSR's central sugar mills

6.3 Part of a sketch plan of Pioneer Sugar Estate, Lower Burdekin, 1888

6.4 The location of the government-funded central sugar mills in Queensland

6.5 A plan of a partially subdivided Macknade plantation, Herbert River district, showing the presence of tenant farmers, c. 1895

7.1 The location of experimental sugar cane nurseries and stations in Australia, 1870-1914

8.1 The juice mill system that operated in the Maryborough and Bundaberg districts, 1870-1914

9.1 Refined sugar production at CSR's Australian sugar refineries, 1890-1914

9.2 Tonnage of sugar produced in Australia, 1868-1914 244

10.1 The area (ha) under sugar cane in Queensland and New South Wales, 1915-1938

10.2 The percentage of Australia's raw sugar production exported, 1924-1995

10.3 World average sugar prices (US cents/lb) by calendar year, 1960-1995 
11.1 The location of terrestrial lime mines and coral reefs mined to produce agricultural lime in Queensland, 1900 - c. 1945

11.2 The percentage of the yearly molasses production used as fertiliser in Queensland, 1928-1970

11.3 Tonnes of inorganic fertilisers applied to sugar cane in Queensland, 1944/1945-1973/1974

11.4 Tonnes of inorganic fertilisers applied per hectare of sugar cane fertilised in Queensland, 1944/1945-1989/1990

11.5 Area (ha) cultivated per farm producing sugar cane for harvest in Australia, 1949-1995

12.1 The number of irrigators in the Queensland Petty Sessions

Districts where sugar cane was irrigated, 1915-1936

398

12.2 Area irrigated (ha) in the Queensland Petty Sessions Districts where sugar cane was irrigated, 1915-1936

12.3 The location of drainage trusts/unions formed in northern New South Wales, 1900-1920

12.4 Area of sugar cane irrigated (ha) in Queensland's Statistical Divisions, 1952/1953-1970/1971

12.5 The percentage of the annual sugar cane crop irrigated in Queensland, 1945/1946-1992/1993

12.6 The Burdekin River Irrigation Area and Burdekin Delta Artificial Recharge Scheme, 1990

12.7 Bundaberg Irrigation Scheme, 1992

12.8 Voluntary drainage schemes formed in the Innisfail district by 1969

12.9 The location and period of establishment of the Far North Queensland drainage schemes, 1960-1990

12.10 Plans of cane farms in the Innisfail district showing how the realignment of Fitzgerald Creek permitted the creation of more regular field layouts

12.11 Richmond River district drainage improvements, 1981

12.12 Area (ha) of sugar cane irrigated in Queensland's Statistical Divisions, 1971/1972-1993/1994

13.1 The percentage of harvested cane in New South Wales classified according to variety, 1915-1936 
13.2 The origin of cane varieties in New South Wales, 1920-1990 476

13.3 The number of cross-pollinations completed annually at the Meringa BSES station, 1940-1995

13.4 The origin of cane varieties in Queensland, 1935-1995

13.5 The percentage of harvested cane in Queensland classified according to variety, 1934-1943

13.6 The percentage of harvested cane in New South Wales classified according to variety, 1937-1959

13.7 The percentage of harvested cane in Queensland classified according to variety, 1944-1959

13.8 The percentage of harvested cane in Queensland classified according to variety, 1960-1977

13.9 The percentage of harvested cane in New South Wales classified according to variety, 1960-1977

13.10 The percentage of area planted in New South Wales classified according to variety, 1978-1994

13.11 The percentage of harvested cane in Queensland classified according to variety, 1978-1995

13.12 Average tonnes of cane per hectare in New South Wales and Queensland for five year periods, 1915/1919-1990/1994

13.13 Average tonnes of sugar per hectare in New South Wales and Queensland for five year periods, 1915/1919-1990/1994

14.1 Estimated annual losses (tonnes of cane) to the Queensland sugar crop from pests, 1960-1979

14.2 Estimated annual losses (tonnes of cane) to the Queensland sugar crop from pests, 1980-1995

16.1 (A): Plan of linear cane barracks (single banked rooms);

(B): Plan of L-shaped cane barracks (single banked rooms)

17.1 The average tonnage of cane crushed yearly by Australian sugar mills, 1915-1945

17.2 The average crushing rate (tonnes per hour) at Queensland sugar mills, 1933-1984

17.3 The average tonnage of cane crushed yearly at Australian sugar mills, 1945-1969 
17.4 The average tonnage of cane crushed yearly at Australian sugar mills, 1970-1995

18.1 Tonnes ('000) of raw sugar melted at CSR's refineries, 1922-1945

18.2 Tonnes ('000) of raw sugar melted at CSR's refineries, $1946-1980$

18.3 Schematic diagram showing the transport arrangements for raw sugar in Australia, 1950 and 1965

18.4 Exports ('000 tonnes) of Australian raw and refined sugar by destination, 1947/1948-1979

18.5 Exports ('000 tonnes) of Australian raw and refined sugar by destination, 1979/1980-1995/1996 


\section{Tables}

5.1 Regional percentage of the total area cultivated with sugar cane in Australia, 1868-1914

6.1 The number of sugar plantations in Australia's sugar-producing regions, $1870-1915$

6.2 Sugar production (tonnes) in Queensland and New South Wales by 'white' and 'non-white' labour, 1902-1912, and numbers of New South Wales canegrowers using 'white' and' 'non-white' labour, 1906-1912

6.3 Average area (ha) of sugar cane cultivated per small canegrower in Queensland and New South Wales, 1906-1914

7.1 The number of cane varieties imported into Queensland, 1890-1914, classified according to country of origin and importer

7.2 The estimated percentage of various cane varieties in a selection of Queensland's sugar-producing districts, 1912

8.1 The number of sugar mills in Queensland and New South Wales, 1864-1914

8.2 The average output per Queensland and New South Wales sugar mill (tonnes of sugar), 1870-1874 to 1910-1914

9.1 Sugar consumption per capita (kg) for selected countries, 1874, 1887 and 1909

9. 2 The number of Australian sugar mill-owners selling their annual output to CSR, 1893-1908

10.1 The number of Queensland sugar mills in excess of the their allocation under the Peak Year Scheme of 1929

10.2 Sugar production statistics for New South Wales and Queensland, 1939-1948

10.3 Sugar production statistics for Queensland, 1949-1963

10.4 Sugar production statistics for New South Wales, 1949-1963 304

10.5 Sugar production statistics for Queensland, 1964-1974 310

10.6 Sugar production statistics for New South Wales, 1964-1974 311

10.7 Sugar production statistics for Queensland, 1974-1984 314

10.8 Sugar production statistics for New South Wales, 1974-1984 317

10.9 Sugar production statistics for Queensland, 1985-1995 323

10.10 Sugar production statistics for New South Wales, 1985-1995 332 
11.1 The average area (ha) cultivated on properties growing sugar cane in Queensland, 1917-1919 to 1934-1939

11.2 The average percentage of the area planted that had been covered by a green manure crop in CSR's mill supply areas, 1927-1945

11.3 The average percentage of trash conservation on the area ploughed out in preparation for planting in CSR's mill supply areas, 1930-1939

11.4 Fertiliser use by the Queensland sugar industry, 1936-1943 357

11.5 The number of wheeled and crawler tractors in Australia's sugarproducing regions, 1958-1959, 1962-1963 and 1968-1969

11.6 Tonnes ('000) of artificial fertilisers used on the crops of sugar cane in Queensland, for selected years between 1974-1975 and 1989-1990

12.1 The percentage of the annual sugar cane crop irrigated in Queensland, 1915-1936

12.2 The length of new drains created and the length of existing drains cleared (metres) in New South Wales mill supply areas, 1959-1964

12.3 The area (ha) irrigated by different methods in selected Queensland shires where sugar cane was the dominant crop in 1962/1963, 1972/1973 and 1978/1979

12.4 The percentage of green cane harvesting in Queensland sugar-producing regions, 1985-1994

13.1 New Q. cane varieties and their year of approval, 1940-1959

13.2 New Q. varieties and their year of approval, 1960-1977

13.3 New Q. varieties and their year of approval, 1978-1995

14.1 The percentage of the area treated in Queensland with particular insecticides to control cane grubs, 1985-1992

15.1 Characteristics of the main diseases affecting the Australian sugar industry, 1920-1955

15.2 The estimated area (ha) affected by major sugar cane diseases in Queensland, 1991-1995

603

16.1 Mechanical cane harvesting and loading statistics for Queensland, 1954-1976

16.2 The percentage of the Queensland sugar cane crop harvested by different types of mechanical cane harvesters, 1960-1971

16.3 The percentage of the sugar cane crop mechanically harvested in New South Wales mill supply areas, 1970-1975 
16.4 The percentage of harvested sugar cane in Queensland delivered by either portable line or road vehicles to mill tramline assembly points, 1951

16.5 Total number of locomotives and rail trucks and length of track at Australian sugar mills, 1952-1978

16.6 The number of mechanical cane harvesters in Queensland and New South Wales, 1971-1995

16.7 The average amount harvested (tonnes) per cane harvester group in Australian sugar-producing regions, 1970-1995

16.8 Categories of mechanical cane harvester ownership in Australia, 1995 season

17.1 Selected crushing statistics for Queensland sugar mills, 1919-1932

702

17.2 The number of different types of effets in selected Queensland sugar mills, 1932-1940

17.3 Type of filtration system used in selected Queensland sugar mills, 1935

17.4 Statistics on milling train arrangements in Queensland's sugar mills, 1951 and 1969

17.5 Statistics on the clarification, evaporation and crystallisation stations of Queensland's sugar mills in 1951 and 1969

17.6 Statistics on milling train arrangements at Australian sugar mills, 1969, 1985 and 1995

17.7 Statistics on the clarification, boiling and crystallisation stations at Australian sugar mills, 1969, $1985 \& 1995$

17.8 The number of Australian sugar mills classified according to ownership, 1925-1995

18.1 Wholesale and retail prices of refined sugar in Australia, July 1915- August 1941

18.2 Exports of Australian raw sugar by destination, 1924/1925-1939/1940

18.3 Initial and subsequent capacity at Australian bulk sugar terminals, 1957-1980

18.4 Australian Sugar Agreements and their impact upon wholesale and retail prices of refined sugar, 1946-1979 


\section{Glossary of Sugar Terms and Definitions}

Affination: The first step in the refining of raw sugar. It involves blending the raw sugar with hot concentrated syrup and spinning off the softened outer syrup layer of the raw sugar crystal in a centrifugal.

Assignment: A right, given by the Central Sugar Cane Prices Board, to grow cane only on a defined section of a property. It is not illegal to grow sugar cane on unassigned land, but raw sugar produced from such cane was paid a penalty price. The Queensland sugar mill to which cane grown on the assignment must be supplied is also specified.

Bagasse: The fibrous residues after the harvested stalks of cane have gone through the sets of crushing rollers. Consists of fibre, water and a small quantity of sugar. It may be used as fuel in a sugar mill's boilers or as a soil enhancement agent.

Barracks: Residential accommodation provided for gangs of canecutters during the crushing season (see crushing season).

Bin: A tramway wagon enclosed with metal or strong wire mesh for carrying cane billets (see cane billets).

Brand 1: The primary Queensland export brand of raw sugar (see raw sugar).

Brand JA: A brand of raw sugar with lower polarisation than Brand 1. It is made for the Japanese market (see raw sugar).

Brix: A unit used to express the concentration of solids in aqueous sugar solutions. For example, $60^{\circ}$ Brix sugar solution contains $60 \%$ by weight of sugar.

Calandria pan: In a calandria vacuum pan, the heating surface consists of a large number of vertical tubes inside the vessel. The juice flows through the tubes, while steam or vapour is directed onto the outside of the tubes.

* This glossary draws heavily on the glossaries contained in the Queensland Sugar Corporation's, Sugar Notes and G. Burrows and C. Morton, The Canecutters (Melbourne, 1986), pp. 262-267.

xxix 
Cane billets: The common name for the chopped lengths of cane (approximately $250-400 \mathrm{~mm}$ ) produced by a mechanical chopper cane harvester during the harvesting operation.

Cane bin: see bin

Cane carrier: A conveyor that carries the harvested cane from the unloading point to the crushing mills (see crushing mill).

Cane inspector: A sugar mill employee who acts as a link between the mill and canegrowers, particularly with regards to estimating the size of the crop and harvesting arrangements.

Cane invert: A liquid sugar product produced at a sugar mill, containing a relatively high proportion mixture of glucose and fructose.

Cane juice: A liquid consisting of water with sugar and other substances dissolved in it and a proportion of insoluble particles suspended in it.

Carbonation: The clarification process of removing impurities from sugar liquor by the addition of lime and carbon dioxide to form calcium carbonate which traps the other impurities. This process is undertaken at a sugar refinery (see liquor).

ccs: Commercial cane sugar. An estimate of the weight of raw sugar that could be obtained from sugar cane, expressed as a percentage of a tonne of cane.

Central/cooperative mill: A term referring to sugar mills built in Queensland either with government grants or loans under Acts in 1886, 1893, 1911 and 1922. These sugar mills were owned by supplier canegrowers (usually between 150 and 300) with suppliers owning the shares in the central milling company.

Centrifugal (fugal): A perforated basket which spins inside a casing to separate sugar crystals from molasses.

Chopper harvester: A mechanical cane harvester which chops the cane stalks into short billets. These are discharged into bins hauled alongside the harvester by tractors (see bin and cane billets).

Clarification: The process of separating insoluble suspended matter and some soluble substances from cane juice, to produce a clear juice. The process 
generally involves adding lime and heating the limed cane juice. Carried out in special vessels known as clarifiers or subsiders (see clarifier).

Clarifier: Large, specially designed vessels where clarification of the cane juice is undertaken. Sometimes known as a subsider. The clear sugar juice is run off from the top of each clarifier. Muddy juice from the bottom of the clarifiers is filtered again using different processes and machinery (e.g. plate and frame presses; rotary vacuum filters) to recover more sugar (see filter mud).

Coefficient of work: A measure of the efficiency of a sugar mill's operation. It represents the recovery of raw sugar (tonnes 94 n.t.) per 100 tonnes ccs in cane.

Crushing mill: Three large rollers arranged in a triangular formation. The shredded cane is fed through these rollers. The process separates the sugar juice from the fibrous material known as bagasse. From 1880 onwards, most Australian sugar mills had two or more sets of crushing rollers known as double, treble, quadruple or quintuple crushing. This arrangement was called a mill tandem or mill train.

Crushing season: The period during which the sugar cane is harvested and crushed at the sugar mills. It generally lasts for 20 to 22 weeks from June to November, but in some years has extended through December and January.

Crystallisation: The process of "growing" sugar crystals by boiling them with syrup in a vessel under vacuum (see massecuite).

Decolourisation: The sugar refinery process whereby the colour of filtered sugar liquor is reduced by passing it over either bone char, granular carbon or ion exchange resin (see liquor).

Diffusion: The process of immersing bagasse or slices of cane in water to 'wash' out the sugar juices. Completed in special units known as diffusion plants or diffusers.

Drop planter: A labour-saving machine that mechanised the planting of setts; first developed in the late 1890s, but widely adopted during the 1920s (see sett).

Effet: Cylindrical steel vessel or evaporator in which a steam heated surface is used to concentrate clear juice from the clarifiers by boiling under a vacuum. 
Multiple effet evaporation occurs in a series of connected effets known as double, triple, quadruple and quintuple effets. The concentrated juice is called syrup and is sent to a vacuum pan (see vacuum pan).

Excess cane: Cane delivered in excess of farm peak (see farm peak).

Excess sugar: Sugar produced by a sugar mill above its peak (see mill peak and Peak Year Scheme).

Extraction: The process of removing sugar and juice from stalks of cane, billets or bagasse, by milling or diffusion.

Extraneous matter: Any material other than harvested cane stalks (e.g. stones, soil, roots, tops and trash) sent to the mill (see trash and top).

Farm peak: A delivery quota which represents a farmer's right to supply cane to a sugar mill to produce a given quantity of sugar. This production control measure was introduced in Queensland in 1939.

Filterability: The filterability of a raw sugar during refining is measured by comparing the filtration rate of the sugar with that of a standard sucrose solution under specified conditions. The result is expressed as a percentage of the filtration rate of the standard sugar.

Filter mud: In clarifying cane juice, the insoluble matter extracted from the juice forms a mud which is removed from the clarifiers, filtered and washed to recover the sugar it contains. Filter mud is used as a fertiliser. Also known as subsider mud, filter cake or filter press (see clarifier).

Filtration: A sugar refinery process whereby cloudy carbonated sugar liquor is passed through filter cloth to produce clear liquor.

Fugal: See centrifugal.

Headland: Areas at the end or head of canefields deliberately left clear of cane. Mechanical harvesters and farm implements can be turned in this space without damaging the crop.

Imbibition: The process of spraying water or cane juice over the blanket of bagasse emerging from each set of crushing rollers to help wash out the sugar.

xxxii 
Juice mill: A primitive sugar mill in which only the cane stalks were crushed. The juice was then sent to another sugar mill equipped with machinery to convert the juice into raw sugar. Found only in the Maryborough, Isis and Bundaberg districts, Queensland.

Levellers: Rotating knives fixed radially on a shaft across the cane carrier. Used to level off thick spots on the carrier feed or to disintegrate the cane stalks before they enter the crushing rollers.

Liquor: Sugar crystals created after affination are dissolved in hot water to form a sugar liquor. This liquor is then carbonated or phosphated to remove remaining impurities (see affination, carbonation and phosphatation).

Local Award or Mill Award: The award made each year by the local board is a contract between the mill-owners and each assignment holder in a particular Queensland mill supply area. It contains an outline of all penalties that applied to diseased, frosted and burnt cane and covers all matters relating to the harvesting and delivery of cane by the canegrower and the transport, payment, handling and crushing of the cane by the mill-owner. Local awards were issued for the first time in 1915 (see mill supply area).

Lodged cane: A crop which has been flattened to ground level by floodwaters, high winds and/or rain.

Maceration: The process in which the bagasse is steeped in an excess of water or cane juice, generally at high temperatures, in order to dissolve more juice out of the baggase.

Massecuite: The mixture of sugar crystals and molasses produced by crystallisation in a vacuum pan. The term is French for 'cooked mass'. A, B and C are grades of purity. A and B are the purest and produce high-grade sugars. Low-grade sugar comes from $\mathrm{C}$ massecuite.

Mill Peak: Production quotas specified in tonnes of raw sugar allocated to Queensland sugar mills. It is the sum of farm peaks in that mill supply area. Raw sugar produced in excess of peak receives the No. 2 Pool price. First introduced in 1930 as a method to avoid over-production (see Pools).

Mill supply area: Localities from which an Australian sugar mill drew its cane supplies. In Queensland after 1915 these localities became fixed and were related to assignments. Mostly incorporated between 100 and 300 farms (see assignment). 
Mill tandem: Two, three, four, five or six sets of crushing rollers. Also known as a mill train. Such an arrangement improved the juice extraction capabilities of sugar mills (see crushing mill).

Mill whites: A partially refined sugar produced in a sugar mill. It is not as pure as refined white sugar.

Molasses: The black syrup, commonly known as 'C' syrup, remaining after the sugar syrup has been boiled and passed through the centrifugals for the last time in a sugar mill or sugar refinery. The sugar it contains cannot be removed economically. This product is stored for later sale, sometimes as a fertiliser, stock feed or to distilleries (see syrup).

Mud: See filter mud.

Net titre (n.t.): An historical measure of the commercial value of raw sugar for refining purposes. Net titre provided a method for expressing different sugar at a standard value and was used for statistical and payment purposes.

Pans: see vacuum pans

Plant cane: The first growth from cane planted the previous season (see ratoon cane).

Peak Year Scheme: An arrangement introduced in 1930 whereby the highest output of sugar for each Queensland sugar mill in any one year since 1915 was taken as the limit of any future year's production. Essentially a measure designed to avoid over-production (see mill peak).

Phosphatation: A process conducted in a sugar refinery. It involves trapping the impurities in a precipitate formed by adding lime and phosphoric acid to the sugar liquor and removing them as a layer from the top of a flotation clarifier.

pol: Polarisation. The sucrose content of sugar, expressed as degrees pol, which is approximately a percentage. A sugar of $98^{\circ}$ pol would contain about $98 \%$ sucrose.

Pools: In Queensland, payment for raw sugar production was made on a pooling basis. For payment purposes, two different pools were calculated between 1930 and 1995 . The No. 1 Pool price was paid on all sugar produced within 
the Mill Peak and the No. 2 Pool price was paid for the remaining sugar produced from cane which had been grown on assigned land.

Ratoon cane: Cane is harvested by cutting the plant off at ground level. The stubble remaining puts out new shoots, and grows into what is known as a ratoon crop. One plant crop is usually allowed to grow two to four ratoon crops. After a final ratoon crop has been harvested the ground is usually ploughed and fallowed for a year. Legumes are sometimes grown on the fallow ground.

Raw sugar: The sugar crystals separated in a centrifugal in a sugar mill. Australian raw sugar is usually produced in two grades of about $98.8^{\circ}$ pol (Brand 1) or $97.6^{\circ}$ pol (Brand JA). Pol is varied to satisfy the requirements of customers (see Brand 1 and Brand JA).

Refined sugar: Sugar which has passed through the refining process that has involved the removal of impurities which impair colour, flavour and longevity, making it more suitable for direct human consumption. Also known as white sugar (see mill whites).

Sett: A piece of cane stalk used as planting material.

Shredder: Machinery used to reduce and shred the harvested stalks of cane into fibrous material and rupture the juice cells.

Stand-over cane: Mature cane, sometimes in excess of peak, left unharvested at the end of the crushing season. This cane can either be allowed to grow another year or may be destroyed.

Stool: The cluster of cane stalks arising from the germination of setts or the regrowth which comes from the stumps and roots of harvested cane (see sett).

Subsider: See Clarifier.

Syrup: A concentrated sugar solution produced by evaporation of water from sugar cane juice in the effets. In sugar refineries, syrup refers to the less pure solution which is spun off crystals in centrifugals (see effets).

Top: Thick stalk and leaf material above the juice-bearing part of the stalk. This part of the cane plant should be removed during harvesting (see extraneous matter). 
Trash: Leaf matter attached to the cane stalk, which ideally should be removed before milling, by either burning or through mechanical harvester cleaning mechanisms.

Toll refining: Toll refining refers to the use of refining assets, for a fee, to process raw sugar into refined sugar. The refined product remains the property of the raw sugar supplier.

Two-year cane: Cane allowed to mature for two years before harvesting, rather than the normal twelve months. Common only in New South Wales.

Vacuum pan: Cylindrical steel vessel in which a steam heated surface is used to boil sugar syrups under partial vacuum at relatively low temperatures (see syrup and massecuite).

White sugar: The common name for refined sugar. 


\section{CHAPTER 1 \\ An Introduction}

Between 1860 and 1915, the river valleys of most coastal regions between Grafton in New South Wales and Mossman in North Queensland were transformed as the forests were cleared and replaced by fields of sugar cane. Several thousand Europeans eventually settled along these river valleys, making their living from the growing of sugar cane, either directly as farmers or as workers in the sugar mills erected to crush the crops of cane. Other settlers followed, providing the goods and services needed by the farmers and workers. At times during this period, thousands of indentured Pacific Islanders also called these river valleys home; historians have estimated that some 63000 Pacific Islanders, mainly from the Solomon Islands and Vanuatu, laboured in the Australian sugar cane fields between 1863 and 1904. ${ }^{1}$ They were also joined by Chinese, Japanese, Javanese and Indians in lesser numbers. The Aboriginal peoples the traditional occupiers of these river valleys - sometimes resisted this invasion by European agriculturalists and their indentured workers, attacking the livestock on the sugar plantations or occasionally burning crops of cane. ${ }^{2}$ Eventually, some Aborigines worked as labourers on the sugar plantations and/or small sugar cane farms. This great transformation in the tropical and sub-tropical littoral of north east Australia took place to satisfy those Europeans living in temperate Australia, who demanded ever increasing amounts of sugar.

Europeans during the eighteenth and nineteenth centuries, especially the British and French, developed a taste for sweet things. As a result, sugar had become an important commodity. Traditionally, sugar for European consumption had been manufactured in the Lesser Antilles (or West Indies), Cuba, Brazil and Louisiana. During the nineteenth century, sugar production in these traditional areas expanded to meet this demand. In addition, sugar production spread to new regions such as Java, Argentina, Natal, Peru, Hawaii, Fiji and Australia. The emergence of an Australian sugar industry was, therefore, part of a wider nineteenth century dispersal of commercial sugar production around the globe.

The Australian sugar industry that developed between 1864 and 1884 had many similarities with other cane sugar industries around the world. The 
sugar cane was grown on plantations or large estates where indentured labourers worked in both the fields and the estate's own sugar mill. These indentured workers, however, were mostly Pacific Islanders, instead of Indians, Chinese or Japanese who made up the bulk of indentured sugar workers elsewhere around the globe. The sugar produced in northern Australia was sent south to capital city-based sugar refineries, much like the movement of sugar from the West Indies to the sugar refineries in Bristol, Glasgow, Liverpool or London. The milling sector of the Australia sugar industry, like the sugar factories in other sugar-producing regions, had been modernised by the adoption of improvements in machinery (e.g. vacuum pans; multiple evaporators) and industrial processes (e.g. double or treble crushing). In contrast, the agricultural sector of the Australian sugar industry remained labour-intensive, just like the field practices of canegrowers in the Americas, Asia and rest of Oceania.

Despite these similarities, there were early signs that the Australian sugar industry would not evolve exactly as its overseas counterparts. During the 1870s, the central milling system emerged in New South Wales. Here, European small farmers, mostly without the aid of indentured workers, grew the sugar cane, and the Colonial Sugar Refining Company (CSR), a joint stock company, operated three, large central sugar mills equipped with the most up-to-date machinery. This arrangement spread to Queensland after 1884, although the Queensland government, not private enterprise, provided the funds to farmer co-operatives to erect their own central sugar mills. This transformation came about because of Queensland government policies that supported the creation of a class of European farmers for social and political reasons. Other Queensland sugar planters during the 1890s and 1900s became proprietary central mill-owners, creating tenanted estates and concentrating their resources on the manufacturing side of operations. In addition, most indentured workers brought to Queensland were not allowed to settle in Australia as workers or small farmers, unlike other sugar-producing regions (e.g. Fiji; South Africa; Mauritius; British Guiana). The newly formed Commonwealth government of Australia introduced legislation in 1901 which applied a protective duty to sugar imports, prohibited the recruitment of Pacific Islanders into Australia after 31 March 1904 and required the majority of Pacific Islanders to be repatriated to their home islands after 1906. Europeans who were paid higher wages took their places in the sugar mills and fields. Consequently, the Australian sugar industry in 1915 was characterised by central mills supplied with cane from family farms owned by Europeans and European field and mill workers (mostly of Anglo-Celtic descent). This system was unique amongst the world's cane sugar industries. ${ }^{3}$ 
The development trajectory of the Australian cane sugar industry over the period 1915-1995 continued making it different from other cane sugar industries. Sugar was produced universally and exclusively by Europeans paid high wages. This feature led to a high degree of mechanisation in both the fields and sugar mills. In addition, the Australian sugar industry until the mid-1980s was controlled comprehensively by government, being 'honeycombed with statutory rules and regulations'. ${ }^{4}$ These regulations ensured Europeans could farm successfully in the tropical and sub-tropical parts of Australia, avoiding over-production and protected from cheaper imports of sugar produced in other countries where workers received considerably lower wages than Australians. ${ }^{5}$

As the Australian sugar industry was deregulated during the late $1980 \mathrm{~s}$ and early 1990s, it began resembling other sugar industries with regards to its exposure to competition from foreign sugar producers and limited government intervention in marketing arrangements (e.g. Mexico). ${ }^{6}$ Yet the Australian sugar industry stood apart from the cane sugar industries in Brazil and the United States, for example, where government policies protected domestic producers and regulated marketing operations. Thus, the marked differences which once existed between the Australian and other cane sugar industries may have narrowed, but the Australian sugar industry in the mid-1990s was still unique, being one of the world's most low cost, technically efficient and deregulated sugar industries, leading the world in the bulk storage, loading and shipping of the product. Moreover, no other major exporter, apart from Cuba, exported such a high proportion of its raw sugar production. ${ }^{7}$

Historical accounts on aspects of the Australian sugar industry have been written by journalists, historians, economic historians and geographers. Their output is voluminous. Published material on the topic, however, falls into four broad categories. Publications in the first category include those glossy booklets or the more substantial and well-researched books produced to celebrate some milestone in the history of a sugar mill. ${ }^{8}$ The late John Kerr, statistician and part-time historian, made a speciality out of writing sugar mill histories, having completed accounts about six Queensland sugar mills and the history of the Bundaberg Sugar Co., which operated four sugar mills during the 1980s. ${ }^{9}$ The second category of publications contains theses and books by both nineteenth and twentieth century authors on the history of sugar production in New South Wales, Queensland or the Northern Territory. ${ }^{10}$ Material in the third category includes the numerous journal articles and books dealing with the labour supply for the Australian sugar 
industry, particularly the trade in Pacific Islanders during the nineteenth century, ${ }^{11}$ the rise of trade unionism amongst European sugar workers and the origins and development of the cane cutting teams that took over the annual cane harvest during the $1900 \mathrm{~s},{ }^{12}$ and the mechanisation of cane harvesting in the 1950s and 1960s. ${ }^{13}$ The fourth category contains studies that deal with the historical development of sugar cane growing as part of a local history or regional study. ${ }^{14}$

Given that so much has been written about different aspects of the Australian sugar industry, how is this book different from previous studies? Firstly, this work takes a national approach. The evolution of sugar production in Queensland, New South Wales, Western Australia and the Northern Territory are linked together, in order to show the broader, overall picture. Moreover, this research acknowledges that although the sugar cane was grown and processed into raw sugar in northern Australia, other parts of the industrythe refiners who further processed the raw sugar into refined sugar and the merchants who sold the raw and refined sugar to consumers - were located mostly in southern Australia. The inter-colonial and inter-state trade in sugar joined Australian regions of sugar production with Australian regions of sugar consumption. In addition, flows of capital from southern Australia during the nineteenth century, especially Victoria, financed the establishment and growth of sugar production in northern Australia.

Secondly, this account is a study in which geographical and environmental questions are paramount. Publications into aspects of the Australian sugar industry by historians and economic historians have often ignored the importance of place, regional differences and the environmental consequences of sugar production. The economic and political forces shaping the development of Australia's sugar industry did not create a homogenous economic or cultural landscape, and the environmental impact of sugar production varied between regions. Commercial sugar production emerged under different arrangements in the various sugar-producing districts throughout the country, the speed of change in the production system during the nineteenth century was not uniform and neither was the impact of post-1930 regulations, particularly controls over production. In addition, quite marked regional differences occurred in the varieties of sugar cane cultivated, the adoption rate of new machinery and farming techniques, the types of disease and pest outbreaks and the ethnicity of workers employed, especially during the late nineteenth century.

Thirdly, this work is an integrated study covering all sectors of the Australian sugar industry. Researchers often overlook the dual nature of sugar 
production. In any cane sugar industry there is an agricultural sector and an industrial sector that is split into milling and refining operations. Historians and economic historians in their studies of the Australian sugar industry have concentrated on the agricultural sector, particularly its labour supply and the transformation of the production system from plantations to central sugar mills supplied by small farmers (i.e. the period 1885-1915). ${ }^{15}$ In this account, however, details have been systematically assembled for the first time on the changing cultivation methods and machinery employed by Australian canegrowers, their fight against pests and diseases, and the assistance they received from the country's agricultural scientists to breed new cane varieties that were suited to the different environments where the crop is cultivated in Australia. Chapters on the evolution of the milling and refining sectors and the marketing of sugar are also provided. These sectors have not been considered previously in any depth or not at all in the standard works on the Australian sugar industry.

The book begins with a brief account of the biology and environmental requirements of sugar cane and explains how sugar cane is converted into raw (or brown) and refined (or white) sugar (Chapter 2). The book is then structured in three sections, covering the main epochs in the historical development of the Australian sugar industry. Part 1 covers the beginnings of the Australian sugar industry from the arrival of Europeans in New South Wales in 1788 to 1863, the year before the commercial production of raw sugar was finally established permanently in Australia. The discussion documents the unsuccessful intermittent attempts to manufacture raw sugar in Australia (Chapter 3), and the growing demand for sugar by convicts and free settlers and its supply by merchants and then the first sugar refiners (Chapter 4). Part 2 comprises five chapters covering the years from the sustained commercial production of raw sugar in 1864 to the outbreak of World War I. This period is when the Australian sugar industry finally becomes established and the foundations for its post-1915 character emerged. Topics covered include the following: the rapid increase in the area cultivated with sugar cane in different parts of Australia (Chapter 5); the transformation in the production unit from plantations to large numbers of small, European-owned family farms supplying sugar cane to cooperative or proprietary central sugar mills (Chapter 6); earliest cultivation methods (Chapter 7); technological change in the milling sector (Chapter 8); and CSR achieving almost a monopoly over the refining and marketing of sugar in Australia by 1914 (Chapter 9). 
The final section covers the years from 1915, when government regulations start controlling all aspects of the production and marketing of sugar in Australia, until 1995, when the Australian sugar industry operated in a mostly deregulated environment. Chapters cover the following topics: the regulation of the growth in the area cultivated with sugar cane to ensure supply matched the domestic and global demand for sugar (Chapter 10); increasing use of labour-saving machinery, fertilisers and herbicides (Chapter 11); the upsurge in drainage- and irrigation-related activities and measures to reduce soil erosion (Chapter 12); breeding new cane varieties (Chapter 13); efforts to combat the impact of pests and diseases upon yields (Chapters 14 and 15); the harvesting of cane and its transport to the sugar mills (Chapter 16); the trend towards fewer sugar mills with quicker and greater processing capacities (Chapter 17); and the inter-linking of the marketing and refining of sugar and its pricing until deregulation in the 1990s (Chapter 18).

Throughout this narrative, primary sources have been used extensively. They have been considered from a different perspective and some material has been examined in a more exhaustive manner than has hitherto been attempted. In particular, a considerable amount of time was devoted to reading through pre-1930 newspapers, magazines, sugar industry journals and mill records and the voluminous pre-1980 archival records of CSR, which revealed not only much about the operation of that company, but details about the agricultural and business practices of other Australian canegrowers and mill-owners. In addition, the following new material was examined: the historical records of CSR's now closed Goondi and Hambledon Mills and the Technical and Field Department of Macknade Mill which were transferred to the Noel Butlin Archives Centre, Canberra, in the mid-1990s; the financial records of the sugar mills and plantations operated by the Queensland National Bank, the Commercial Banking Company of Sydney and the Union Bank of Australia Ltd. (located at the archives of the National Australia and ANZ Banks, Melbourne); and the order books of the Scottish engineering firms involved in the manufacturing of the machinery for the sugar mills in Queensland during the nineteenth century (found at the Business Records Centre, Glasgow University Archives). To my knowledge, none of this material has been considered previously in any depth, if at all, for information about the Australian sugar industry. Therefore, the primary sources used as the basis for the narrative in this book will add a new dimension to understanding the historical development of the Australian sugar industry. 


\section{Notes}

1 C. Price with E. Baker, 'Origins of Pacific Island labourers in Queensland, 1863-1904: a research note', Journal of Pacific History, Vol. 11 (1976), p. 116.

2 D. Jones, Trinity Phoenix. A History of Cairns (Cairns, 1976), p. 162; J. Kerr, Sugar at Maryborough: 120 years of Challenge (Maryborough, 1987), p. 15; North Queensland Herald, 6 April 1892, p. 13; S. May (ed.), 'The Diary of Arthur Neame, 1870-1897', pp. $33 \& 36$, JOL.

3 H. Blume, Geography of Sugar Cane (Berlin, 1985), p. 210.

4 F. Maxwell, Economic Aspects of Cane Sugar Production (London, 1927), pp. 9-10.

5 A. Graves, 'Crisis and change in the Australian sugar industry, 1914-1939', in W. Albert \& A. Graves (eds.), The World Sugar Economy in War and Depression (London, 1988), pp. $142-156$.

6 For these measures see G. Robinson, 'Deregulation and restructuring of the Australian cane sugar industry', Australian Geographical Studies, Vol. 32, no. 2 (1995), pp. 221-227.

7 Sugar Industry Review Working Party, Sugar-winning globally. Report of the Sugar Industry Review Working Party, pp. 1 \& 7; for details about the regulation of different sugar industries see T. Sheales, S. Gordon, A. Hafi and C. Toyne, Sugar: International Policies Affecting Market Expansion. ABARE Research Report 99.14 (Canberra, 1999).

8 For these booklets see these references listed in the bibliography: Anon (1984); Landells (1937); \& Pioneer Sugar Mills (1984); for more substantial publications on the same theme see the following references: Alcorn and Dunn (1997); Hudson (1995); Hudson (2000); Langford and Thomis (1979); Manning (1983); Morton (1995); \& Rolleston (1987).

$9 \quad$ See these references in the bibliography: Kerr (1979); Kerr (1983); Kerr (1987); Kerr (1988); Kerr (1991); Kerr (1996); \& Kerr (1997).

10 For nineteenth century authors see the following references listed in the bibliography: Roth (1880); Mackay (1883) \& Fletcher (1886); for twentieth century studies on Queensland see the following references in the bibliography: Adamson (1953); Easterby (c. 1933); \& Shogren (1980); for twentieth century studies on New South Wales see the following references in the bibliography: Higman (1968) \& Jeans (1972, pp. 239-250); for the Northern Territory see Hillock (2000).

11 For nineteenth century commentators see the following references in the bibliography: Roth (1883) \& Black (1894); for more recent discussions see the following references in the bibliography: Corris (1970); Corris (1973); Gistitin (1995); Graves (1993); McGrath (1976); Mercer (1995); Moore (1985); Saunders (1979); Saunders (1982); Shlomowitz (1981); Shlomowitz (1982); \& Shlomowitz (1985).

12 See the following references in the bibliography: Armstrong (1983); Hunt (1978); Saunders (1978); \& Shlomowitz (1979).

13 See the following references in the bibliography: Burrows and Shlomowitz (1992); Department of Labour and National Service, Australia (1970); Kerr and Blyth (1993); \& Willis (1972).

14 For nineteenth century accounts see the following references in the bibliography: Goodwin (1883) \& Munro (1895); for more recent publications on Queensland see the following references in the bibliography: Collinson (1945); Dignan (1964); 
Gaylard (1967); Gregory (1991); Griggs (1990); Jones (1973); Jones (1976); Kerr (1980); Kerr (1994); May (1984); \& Wegner (1984); for more recent publications on the New South Wales sugar industry see the following references in the bibliography: Daley (1966); Davies (1953); \& Smith (1991).

15 For examples see A. Graves, 'Crisis and change in the Queensland sugar industry, 1862-1906', in W. Albert \& A. Graves (eds.), Crisis and Change in the International Sugar Economy 1860-1914 (Norwich, 1984), pp. 261-279 \& R. Shlomowitz, 'The search for institutional equilibrium in Queensland's sugar industry, 1884-1913', Australian Economic History Review, Vol. 19 (1979), pp. 91-122. 